\title{
Social Construction of Mass Media in the Indonesian Presidential Election; A Framing Analysis of the 2019 Indonesian Presidential Debate
}

\author{
AB Sarca Putera ${ }^{1(*)}$, Nurlizawati $^{1}$, Ike Sylvia $^{1}$, Eka Novita Sari ${ }^{1}$ \\ ${ }^{l}$ Dep. of Sociology Education, Faculty of Social Sciences, Universitas Negeri Padang, Indonesia \\ ${ }^{*}$ Corresponding author.Email: ${ }^{(*)}$ absarcaputera@fis.unp.ac.id, nurlizawati@fis.unp.ac.id,
}

\begin{abstract}
This study discussed the 2019 Indonesian Presidential Election, which was constructed by online mass media. Since mass media and politics are two inseparable things, they have attractive mutual interests. On this basis, the presumption that the process of news production, editorial policy and the ideal values of journalism itself influenced by the ties of power related to the interest of the mass media owners and also the political interest is established. This research specifically discussed the news published by tempo.co and republika.co.id about the 2019 presidential election as research objects. This study used the Zhondang Pan and Gerald M. Kosicki models for framing research. The results showed that in framing the news both tempo.co and republika.co.id corresponded to two extreme points, having variations and having similarities. It is more significant because of the mass media's ideology than the mass media's ownership factor.
\end{abstract}

Keywords: Framing, presidential election, News, Mass Media

\section{INTRODUCTION}

The role of journalism as the fourth estate and watchdog cannot be separated from the developmental history of journalism itself. This position is preferably a part in keeping with political developments. As a product of democracy, journalism requires the existence of press freedom to represent the public as monitors and guardians of political actors' accountability. Journalism should, therefore, be present in this context as the transmission of political information to the public with the goal of increasing people's understanding of politics and becoming indirectly a control mechanism over every political activity. Specifically, the information conveyed can be used by the community to determine who they want to hold power (Steel, 2009: 587). Therefore, journalism cannot be separated from democratic political life. Mass media presence is, of course, vital as a bridge between these two issues.

In the historical record of the United States (US), published online by the Library of Congress, during the Presidential Debate between Richard Nixon and John F. Kennedy, the unprecedented relationship between mass media and politics took place. Thirty million television viewers watched the debate on September 26, 1960. According to US political polling firms at the time, the event known as "The Great Debates" became the basis for 3.4 million voters to decide their preference of political party in elections (www.americaslibrary.gov). From the mass media viewpoint, particularly television, this event has become a milestone in US political life. Meanwhile, from an academic point of view, "The Great Debates" becomes a separate study to see the effects, influence, and substance of the relationship between mass media and politics (Benoit, Hansen, \& Verser, 2003; Drury \& Herbeck, 2015).

The relationship between the mass media and politics undergoes changes during its progress, which inevitably has implications for the ideal context of journalism. The relationship of the mass media and politics is depicted in the concept of mediation, where the mass media has an autonomous power in the world of politics so that it no longer relies on political logic but follows its own professional and commercial logic. Hence the role of the mass media in influencing informal rules in political dynamics is more essential (Vliegenthart \& Skovsgaard, 2017: 89). The mass media has the indirect power to select, interpret and create political news messages and urge politicians to conform to their logic (Baugut \& Scherr, 2018). This is what makes the mass media progressively has a keen interest and impact in today's modern culture and the political world.

Furthermore, mass media can also be interpreted as political actors and institutions due to its ability to politically choose and frame news. Therefore, the media has the ability to influence political processes and outcomes (Thesen, 2017: 31). Additionally, according to Peter Van Aelst and Stefaan Walgrave in his journal 
entitled Information and Arena: The Dual Function of the News Media for Political Elites, mass media has a dual function for political actors. The first is as information, both as pure sources of information and as information used by politicians. Second, it functions as an arena where mass media is a unique place to attract public attention (Aelst \& Walgrave, 2016). In these two functions, there is a conflict of interest between the mass media and politics.

Being based on the aforementioned, in the context of mass media development and political situation in Indonesia currently, it becomes crucial to investigate the role of the mass media in constructing the 2019 Indonesian Presidential Election. In a broader perspective, in his book Media Power in Indonesia: Oligarchs, Citizens and the Digital Revolution," Ross Tapsell stated that "in the context of Indonesia, the media king became an increasingly influential political player, and contributed to far more partisan news and information coverage" (Tapsell, 2018: 11). Therefore, this study will specifically scrutinize the framing of the 2019 Indonesian Presidential Debate news in the online media tempo.co and republika.co.id. The selection of the 2019 Indonesian Presidential debates departs from a number of study results showing that reporting on US presidential election debates have a significant impact, both on society in particular, and on the political dynamics of the country itself in a broader context (McKinney \& Warner, 2013; Turcotte, 2015). Meanwhile, similar studies are rarely conducted in Indonesia, because they focus more on other types of political news, and they all study news in print-based mass media (Hamad, 2004; Chairani \& Kania, 2014; Sapahuma, 2015; Siregar, 2019). A study which specifically highlighted the debates of 2019 Indonesian Presidential Election was conducted by Dwinarko (2019) titled Drama of Social Media Political Actors in Democracy Facebook Public Space and Democratic Practices in the 2019 Presidential Debate in Indonesia. However, it did not focus on news and mass media, but on social media users' behavior.

The purpose of this study is to fill in the gaps that are seldom filled by researchers or other studies, on which the online mass media framing is conducted by tempo.co and republika.co.id towards the 2019 Indonesian Presidential Election debate. The answer to this led this research to find and clarify the social construction in the 2019 Indonesian Presidential Election portrayed by the mass media.

\section{METHOD}

The primary key to framing is the selection of certain realities that appear prominently in a communication text; in this case, the news text. So, the chosen fact is more reminiscent and relevant to the audience (Eriyanto, 2018: 72), without framing, therefore, we will find it difficult to find relationships between events and also to understand the world around us. In the context of this research, framing cannot be isolated from the attempts of the mass media to construct reality. The framing is an instrument to tell a narrative for organizations and mass media staff. In line with that, in its coverage, political reality is the key attraction for the mass media. The potential conflict of interest between the mass media and political actors in a study is not only related to the degree of power relations, but also to the ideal principles of journalism (Scheufele \& Iyengar, 2017: 683).

The framing analysis model used in this study is the approach proposed by Zhongdang Pan and Gerald M. Kosicki, where they divide the news text into four structural dimensions, namely: syntax, script, thematic, and rhetorical. The syntax is about how journalists write news while the scripts are a way in which reporters can describe events in news form while thematic is how journalists write facts and as for rhetoric is a journalist's way of emphasizing facts (Pan \& Kosicki, 1993; Sobur, 2009: 175-176). Those four dimensions used to analyze the news scope provided by the online mass media; tempo.co and republika.co.id for the 2019 Indonesian presidential election debate. Framing analysis results then studied the construction of social media in the 2019 Indonesian Presidential Election. From a broader perspective, the news is the product of an effort to tell an event, condition or entity, including politics-related matters seen as an effort to create reality (Hamad, 2004). The term construction of social reality is initially derived from Peter L. Berger and Thomas Luckmann's thoughts through their book titled The Social Construction of Reality: A Treatise in the Sociological of Knowledge (1966). The social reality is humanly generated and interpreted. However, in its development, the theory of the construction of social reality from Berger and Luckmann was revised by Burhan Bungin in his book titled Social Media Mass Construction: The Power of Influence of Mass Media, Television Advertising and Consumer Decisions and Criticism of Peter L. Berger and Thomas Luckmann (2011). The "social media construction" task is to correct the substance of deficiencies and complete the "social construction of reality," whereby the rapid and widespread dissemination of information leads to very rapid and widespread social construction. Thus, the constructed reality will ultimately influence in shaping public opinion (Bungin, 2011: 194; Karman, 2015; Santoso, 2016). Based on these premises, the whole substance of the mass media is a constructed reality that forms the mass construction of social media.

The principal reason behind the selection of these two electronic mass media is that tempo.co (1995) and republika.co.id (1995) considered as the initial generation of online mass media in Indonesia (https://www.tempo.co/about; https: //www.republika.co.id/page/about; Margianto and Syaefullah, 2014: 15-16). Besides, the factors of mass media ownership, media coordination, and ideology are different between tempo.co and republika.co.id (Tapsell, 2018: 102-111), which is also a strong reason for the selection of these two online mass media. Meanwhile, from the five debates in 2019 Indonesian Presidential Election scheduled by the Indonesian Election Commission, only two debates analyzed because only these two debates presented both two candidates for the Presidential Candidate, and the Vice-Presidential 
Candidate. The debates analyzed were the First Debate on Law, Human Rights, Corruption and Terrorism on January 17, 2019, also the Fifth Debate on Economics and Social Welfare, Finance and Investment, also Trade and Industry on 13 April 2019.

There were 6 news items examined from the 2019 Indonesian Presidential Election debates reports. The choice of this news emerged from a study review conducted by the researchers towards the news released by tempo.co and republika.co.id. The initial step was finding the news keywords that the two online mass media used in indexing their news about the 2019 Indonesian Presidential Election debate. On republika.co.id, for the vice presidential candidate debates, researchers found 47 news items covering the first debate and five reports that addressed the fifth debate. While on tempo.co using the same keyword of the presidential election debate, researchers did not find any news covering the first debate, however, there were 12 news items covering the fifth debate. So, in line with that, the data collection techniques in this research were thus based on documents and literature study and, audio-visual materials.

During the selection process, six news items were chosen and analyzed by the researchers. The news using the poliainment rationale was disabled. This applies to the news that incorporates political news as entertainment; episodic news that analyses pieces of broken events; and news that relies on the "reality in making" claim where the verification and validation process is periodically performed, not entirely in one news (Arief, 2017; Ambardi, 2015). For the first debate news on tempo.co, researchers relied on the hypertext or hyperlink feature used on its news agency. The researchers then adjusted the time context, themes, and the two online news issues in the mass media.

\section{RESULT AND DISCUSSION}

Research findings show that two examples of online mass media, tempo.co and republika.co.id, are at two extreme points, despite differences and similarities. On the four news items about the first debate on Law, Human Rights, Corruption and Terrorism, both tempo.co and republika.co.id highlighted the inability of the two presidential and vice-presidential candidates to master the subject of discussion, as well as their failure to provide widely anticipated responses and policy proposals expected by the public. In addition, when covering the first debate, both tempo.co and republika.co.id used only one news resource and a main expert from the officials' institution/organization to look specifically at issues related to the topic of the debate. This demonstrates the attempts of the mass media to achieve statements of fact, and establishes objectivity by relying on certain authorities. This framing attempt can be seen from the headline, as in the table 1 .

Table 1. Indonesia Presidential Election Debate News Table 2019 at tempo.co and republika.co.id

\begin{tabular}{ccc}
\hline $\begin{array}{c}\text { Online Mass } \\
\text { Media }\end{array}$ & First Debate News & $\begin{array}{c}\text { Fifth Debate } \\
\text { News }\end{array}$ \\
\hline
\end{tabular}

\begin{tabular}{lll}
\hline tempo.co & (a) Presidential & Four Critics \\
& Election Debate, & from Prabowo \\
National Human & of Economic \\
Rights Commission & Problems \\
& regarded the 2 & Against Jokowi \\
candidates do not & in the Fifth \\
& understand Human & Debate \\
& Rights context &
\end{tabular}

Rights context

(b) Amnesty: There

Is No Concrete

Solution About

Human Rights in the

First Presidential

Debate.

\begin{tabular}{lll}
\hline republika.co.id & (a) ICJR: Presidential & \multicolumn{2}{l}{ Prabowo-Sandi } \\
& Election Debate Does & Offers the \\
& Not Answer Legal & Direction of \\
& Problems in & Changing \\
& Indonesia. & Economic \\
& (b) PARA Syndicate: & Policy \\
& First Presidential & \\
& Election Debate & \\
Minimizes Data &
\end{tabular}

Source: Researcher Processed

Implicitly, this also shows a fundamental difference in framing the news about the debate issue; tempo.co is more focused on issues of human rights. Whereas, republika.co.id focuses more on legal issues and always addresses extremism that is not religiously linked. This becomes relevant when reflecting on the viewpoint of each online mass media expressed in their vision and mission, in this case, tempo.co emphasizes more on "building a civilization that respects intelligence and differences, accommodating and distributing a fair share of different voices - reflects the diversity of Indonesia"(https://korporat.tempo.co/tentang/visi).

Meanwhile, republika.co.id's vision and mission is to present the principles of modernism, Islamism, and professionalism or what is often referred to as people's media (Febriani, 2010; Tapsell, 2018: 108).

On the two news about the fifth debate on Economy and Social Welfare, Finance and Investment as well as Trade and Industry, tempo.co, and republika.co.id both highlighted criticism from Prabowo - Sandiaga Uno towards Joko Widodo - Ma'ruf Amin. However, the difference lies in the portion given in the body of the news. There is an effort to maintain consistency in the news published by tempo.co, by providing a portion of criticism and refutation to the two candidates; all comments were accommodated in the news-press. On the other hand, in republika.co.id's news release, the entire news portion covered only utterances from one candidate; PrabowoSandiaga Uno. Implicitly, in the coverage of the fifth debate, it reveals that the statement by Erick Thohir as chairman of the National Campaign Team Joko WidodoMa'ruf Amin which could affect the editorial policy of republika.co.id online is indisputable. The same thing was also found in research conducted by Ballian Siregar 
(2019), that the editorial policy of the Republika Daily was not influenced by media owners.

Being based on the results of the framing analysis, the construction of mass media social which was built from 2019 Indonesian Presidential Election is the inability of the two candidates for President and Vice President to master essential issues in managing the country. Especially on the issues of Law, Human Rights, Corruption and Terrorism which becomes a milestone for a country. However, with this construction the organization is expected to continue to oversee government and policymakers ' working when dealing with the issues of Law, Human Rights, Corruption, and Terrorism.

This study only studied framing news texts and the absence of interviews with journalists and mass media editors. Therefore, continuing this study at the next level is important in order to obtain comprehensive outcomes, particularly studying framing in the editorial room, individual framing and also social framing.

\section{CONCLUSION}

With its pace and wider reach, online mass media meets the elements which constitute the substance of the theory of social media construction. However, in the context of framing, reflecting on this the news is often limited by the speed itself. Consequently, the news content tends to be unified since it has to be first to publish the news. Therefore, the disparity in the news frame is more noticeable if it is related to the mass media agenda than other components.

\section{ACKNOWLEDGMENTS}

Researchers would like to thank Ms. Ike Silvya for guidance and support in completing this research. Also, Eka Novita Sari as a research assistant who has helped in collecting data. Finally, the researchers would like to thank Universitas Negeri Padang for funding the research through PNBP 2019 scheme.

\section{REFERENCES}

[1] Aelst, Peter Van \& Walgrave, Stefaan. (2016). Information and Arena: The Dual Function of the News Media for Political Elites. Journal of Communication. DOI:10.1111/jcom.12229.

[2] Ambardi, Kuskridho. (2015). Truth in The Making. Digi-journalism.

[3] Baugut, Philip \& Scherr, Sebastian. (2018): Should the Media Be More or Less Powerful in Politics? Individual and Contextual Explanations for Politicians and Journalists, Political Communication, DOI: 10.1080/10584609.2018.1517844

[4] Benoit, William L., Hansen, Glenn J. \& Verser, Rebecca M. (2003) A Meta-analysis of The Effects of Viewing U.S. Presidential Debates, Communication Monographs, 70:4, 335-350. DOI: $10.1080 / 0363775032000179133$
[5] Berger, Peter L., and Luckmann, Thomas. (1966). The Social Construction of Reality: A Treatise in the Sociological of Knowledge.

[6] Bungin, Burhan. (2011). Konstruksi Sosial Media Massa: Kekuatan Pengaruh Media Massa, Iklan Televisi dan Keputusan Konsumen serta Kritik Terhadap Peter L. Berger dan Thomas Luckman.

[7] Chairani, Dessita \& Kania, Dessy. (2014). Konstruksi Realitas Dalam Pemberitaan Pelantikan Presiden Joko Widodo: Analisis Framing pada Laporan Utama Majalah TEMPO dan Majalah GATRA. Journal Communication Spectrum, Vol. 3 No. 2.

[8] Drury, Sara A. Mehltretter \& Herbeck, Dale A. (2015): Remembering and Re-Creating the Great Debates of 1960: Presidential Libraries as Sites for Political Argumentation, Communication Quarterly. DOI: 10.1080/01463373.2015.1103283

[9] Dwinarko. (2019). The drama of Social Media Political Actors in Democracy Facebook Public Space and Democratic Practices in the 2019 Presidential Debate in Indonesia. Advances in Social Science, Education and Humanities Research, Vol 343.

[10] Eriyanto. (2018). Media dan Opini Publik: Bagaimana Media Menciptakan Isu (Agenda Setting), Melakukan Pembingkaian (Framing) dan Mengarahkan Pandangan Publik (Priming). Depok: RajaGrafindo Persada.

[11] Hamad, Ibnu. (2004). Konstruksi Realitas Politik Dalam Media Massa: (Studi Pesan Politik Dalam Media Cetak Pada Masa Pemilu 1999). Makara, Sosial Humaniora, Vol 8, No 1.

[12] Karman. (2015). Konstruksi Realitas Sosial Sebagai Gerakan Pemikiran: (Sebuah Telaah Teoretis Terhadap Konstruksi Realitas Peter L. Berger). Jurnal Penelitian dan Pengembangan Komunikasi dan Informatika, Vol 5 No. 3.

[13] Margianto, Heru J dan Syaefullah, Asep. 2013. Media Online: Pembaca, Laba dan Etika, Problematika Praktik Jurnalisme Online di Indonesia. Jakarta: AJI.

[14] McKinney, Mitchell S \& Warner, Benjamin R. (2013). Do Presidential Debates Matter? Examining a Decade of Campaign Debate Effects, Argumentation, and Advocacy, 49:4, 238-258. DOI: $10.1080 / 00028533.2013 .11821800$

[15]Pan, Zhongdang \& Kosicki, Gerald M. (1993). Framing analysis: An approach to news discourse, Political Communication. 10:1, 55-75. DOI: 10.1080/10584609.1993.9962963.

[16] Santoso, Puji. (2016). Konstruksi Sosial Media Massa. Al-Balagh, Vol 1 No 1.

[17] Sapahuma, Nacota Yeshida. (2015). Realitas Politik Dalam Media Massa (Konstruksi Pemberitaan Media Massa Seputar 100 Hari Pemerintahan Jokowi-JK). Politika, Vol 6 No 1. 
[18] Scheufele, Dietram A. \& Iyengar, Shanto. (2017). The State of Framing Research: A Call for New Directions. In Kenski, Kate \& Jamieson, Kathleen Hall (Ed), The Oxford Handbook of Political Communication (pp 682-696). New York: Oxford University Press.

[19] Siregar, Ballian. (2019). Framing Berita CapresCawapres Pada Pilpres 2019 Di Harian Umum Republika Dan Koran Tempo. Komunikologi, Vol 6 No 1.

[20] Sobur, Alex, 2009. Analisis Teks Media : Suatu Pengantar Untuk Analisis Wacana, Analisis Semiotik, dan Analisis Framing. Bandung : PT. Remaja Rosdakarya.

[21] Steel, Jhon. (2009). The Idea of Journalism. In Eadie, William F (Ed), 21st Century Communication: A Reference Handbook Volume 1\&2 (pp. 583-591). California, USA: SAGE Publications, Inc

[22] Tapsell, Ross. (2018). Kuasa Media di Indonesia: Kaum Oligarki, Warga, dan Revolusi Digital. Jakarta: Marjin Kiri.

[23] Thesen, Gunnar. (2017). An Intervening Intermediary: Making Political Sense of Media Influence. In Aelst, Peter Van \& Walgrave, Stefaan (Ed), How Political Actors Use the Media: A Functional Analysis of the Media's Role in Politics (pp 21-37). Hampshire: Palgrave Macmillan.

[24] Turcotte, Jason. (2015). The News Norms and Values of Presidential Debate Agendas: AnAnalysis of Format and Moderator Influence on Question Content. Mass Communication and Society, 18:239-258. DOI: $10.1080 / 15205436.2014 .893362$

[25] Vliegenthart, Rens \& Skovsgaard, Morten. (2017). Too Powerful or Just Doing Their Job? Explaining Differences in Conceptions of Media Power Among Politicians and Journalists. In Aelst, Peter Van \& Walgrave, Stefaan (Ed), How Political Actors Use the Media: A Functional Analysis of the Media's Role in Politics (pp 85-103). Hampshire: Palgrave Macmillan.

[26] Tempo Media Grup. (2019). Visi dan Misi. Retrived from https://korporat.tempo.co/tentang/visi

[27] Tempo. (2019). Tentang Kami. Retrieved from https://www.tempo.co/about.

[28] Republika. (2019). Profil. Retrieved from https://www.republika.co.id/page/about

[29] The Library of Congress. (1960). The Great Debates of Nixon and Kennedy. Retrieved from http://www.americaslibrary.gov/jb/modern/jb_mo dern_debates_1.html

[30] Arief, Yovantra. (2017). Politainmen: Gubernur Baru Jakarta. Retrieved from http://www.remotivi.or.id/amatan/429/politainmen t-gubernur-baru-jakarta

[31]Febriani, Ina Salmah. (2010). Analisis Deskriptif Manajemen Redaksi Pada Republika Online (Thesis). Retrieved from http://repository.uinjkt.ac.id/dspace/bitstream 